\title{
İleri yaşta saptanan fibröz displazi: olgu sunumu
}

\section{Fibrous displasia in elderly; case report}

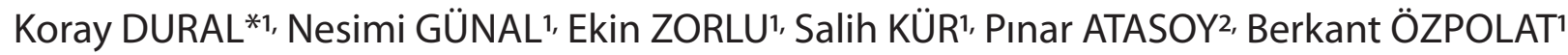

${ }^{1}$ Kırıkkale Üniversitesi Tıp Fakültesi, Göğüs Cerrahisi ABD, Kırıkkale/Türkiye

${ }^{2}$ Kırıkkale Üniversitesi Tıp Fakültesi, Patoloji ABD, Kırıkkale/Türkiye

\section{öz}

Fibröz Displazi fibroosseöz dokunun medüller kemiğin yerini aldığı, özellikle kraniyofasiyal kemikler, uzun tübüler kemikler ve kosta tutulumu gösteren benign karakterde bir lezyondur. Bu olgu sunumunda 64 yaşında asemptomatik hastada malign dönüşüm ihtimali, kotta destrüksiyona ve patolojik kırıklara yol açabilme potansiyeli nedeniyle en bloc rezeksiyon uygulanan bir hastayı literatür eşliğinde sunduk.

Anahtar Kelimeler: Fibröz displazi, kosta, en blok rezeksiyon

\section{ABSTRACT}

Fibrous dysplasia a is benign lesion involving especially craniofascial bones, long tubular bones and ribs where medullary compartment of bone is displaced with fibroosseous tissue. In this case report we aimed to present the management of a 64-year-old man who undergone an enblock costal resection due to the malignacy potential costal destruction and patologic fracture risk.

Keywords: Fibrous dysplasia, rib, resection en block

Sorumlu Yazara: Koray Dural, Kırıkkale Üniversitesi Tıp Fakültesi, Göğüs Cerrahisi ABD, Kırıkkale/Türkiye E-posta: koraydural@yahoo.com

Received 15.06.2017 accepted 17.10.2017

Doi: $10.18663 /$ tjcl.321679 


\section{Giriş}

Illk kez 1938 yılında Lichtenstein tarafından tanımlanan fibröz displazi (FD) , fibroosseöz dokunun meduller kemiğin yerini aldığı, özellikle kraniyofasiyal kemikler, uzun tubuler kemikler ve kosta tutulumu gösteren benign karakterde bir lezyondur [1]. Etyolojisi kesin olarak bilinmeyen, genellikle çocukluk ya da adelosan dönemde görülen FD'yi ileri yaşta saptanan bir vaka nedeniyle sunduk.

\section{Olgu}

64 yaşında erkek hasta $\mathrm{KOAH}$ şüphesi nedeniyle çekilen Toraks Bilgisayarlı Tomografide (BT) de kotta lezyon saptanması üzerine sevk edilmiş. Hastanın lezyona yönelik herhangi bir şikayeti yoktu, fizik muayenede lezyon palpe edilemedi. Laboratuvar bulguları normaldi. Akciğer grafisinde" sol 4.kot lateralde düzgün sınırlı lezyon" (Resim 1) , Toraks BT' de "sol 4. kostada kemik korteksi ile devamlılık gösteren kemik lezyonu, ön tanı osteokondrom olarak raporlandı (Resim 2). Radyolojik olarak ayırıcı tanı yapılamayan hastaya önce kemik biyopsisi yapıldı ve sonucun fibroosseoz doku olarak rapor edilmesi üzerine genel anestezi altında boyutları $8 \times 5 \times 5 \mathrm{~cm}$ 'lik lezyon total olarak rezeke edildi (Resim 3). Histopatolojik inceleme osseofibröz displazi, sol 4. kot olarak rapor edildi (Resim 4). Hasta sorunsuz olarak postoperatif 2. günde taburcu edildi. Kontrollerinde şikayeti olmadığı öğrenildi.

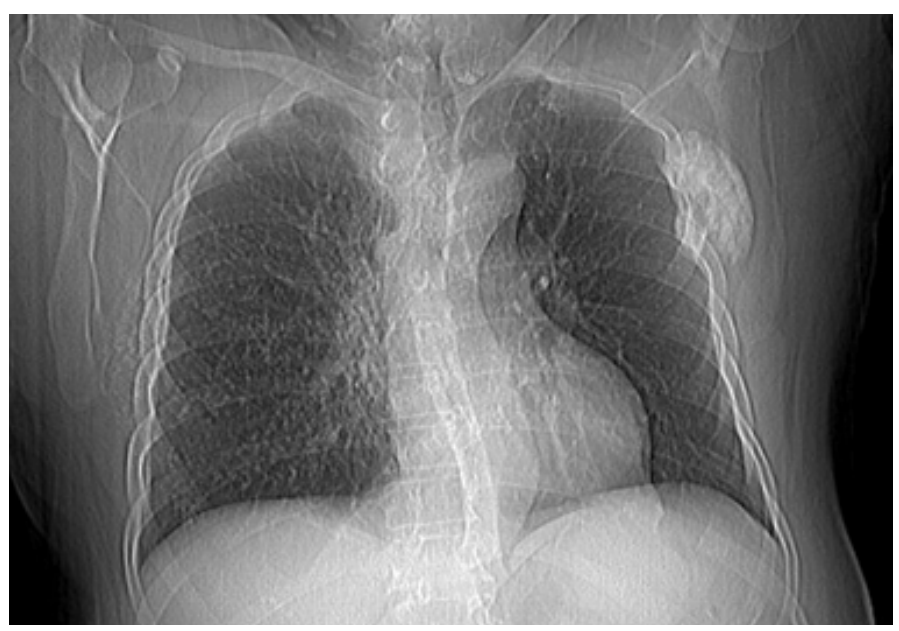

Resim 1. Akciğer grafisinde sol hemitoraksta lezyon izlenmektedir.

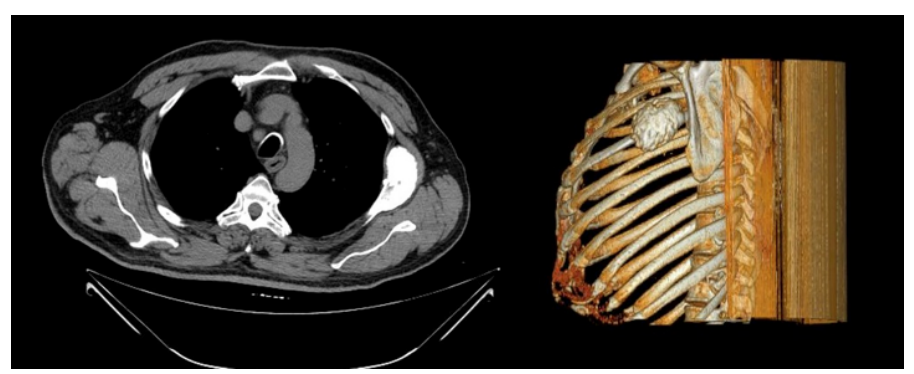

Resim 2. Toraks Bilgisayarlı Tomografide; a) aksiyel kesit, b) Üç boyutlu konfigürasyonda fuziform kitle görülmektedir.

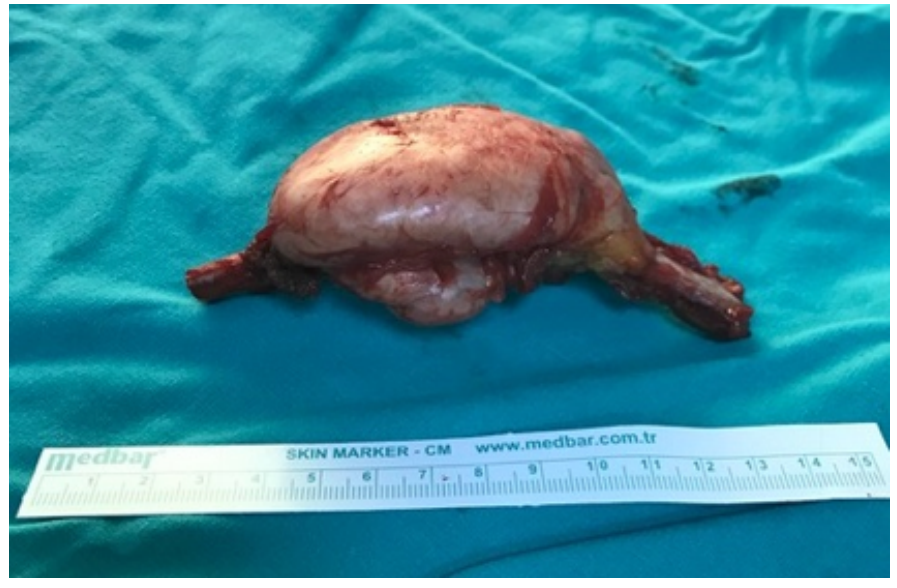

Resim 3. Cerrahi spesimen, kitle $8 \times 5 \times 5 \mathrm{~cm}$ boyutlarındadır.

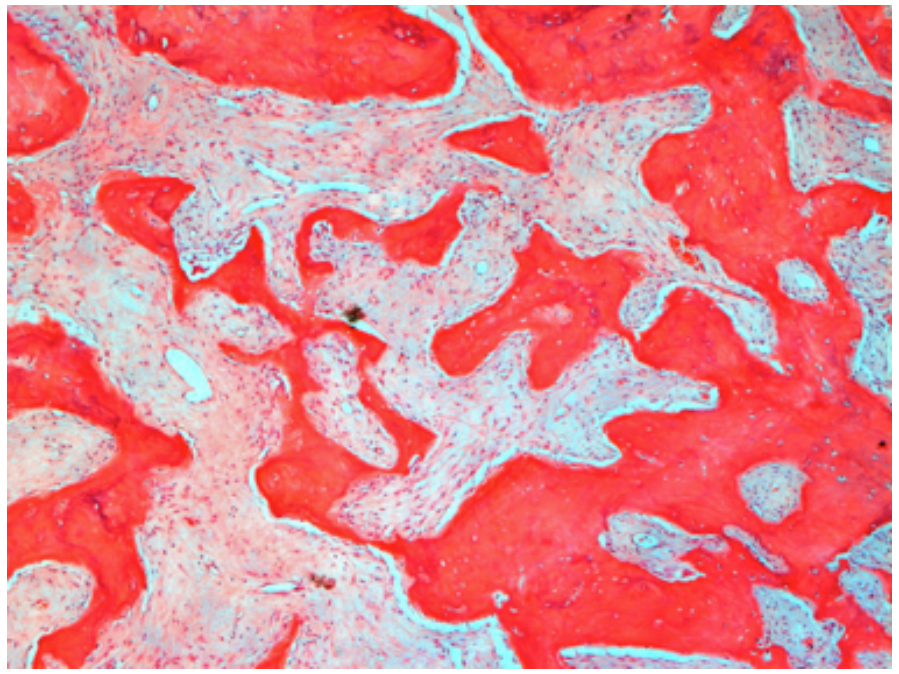

Resim 4. Hiposellüler fibroblastik stromada düzensiz kıvrımlanma gösteren kemik trabekülaları izlenmektedir (H-E, X40).

\section{Tartışma}

Fibröz displazi göğüs duvarının sık görülen benign lezyonlarından biridir. Genellikle çocukluk ve adolesan çağda görülürlerse de erişkinlerde de bildirilmiştir. Etyolojisi kesin olarak bilinmemekle birlikte somatik mutasyon sonucu meydana geldiğini bildiren yayınlar mevcuttur [1-8].

FD iki form halinde görülür. Monostotik fibröz displazi (MFD) tüm vakaların yaklaşık \%80'idir ve sık olarak kosta, proksimal femur, tibia ve kafatasında yerleşir. Çoğunlukla asemptomatiktir, şekil bozukluğuna yol açmaz ve teşhis sıklıkla başka bir sebeple yapılan radyolojik incelemeler ile konulur $[1,3,4,8,9]$. Bizim vakamızda da ileri yaşlara kadar herhangi bir şikayet yapmaması ve muayene bulgusu vermemesi nedeniyle fark edilmemiştir. "Polystotic fibröz displazi" (PFD) kalan \%20'dir, büyük kemiklere yerleşme eğilimindedir ve ek olarak ileri kemik şekil bozukluklarına ve patolojik kırıklara yol açabilir. Bazı sendromlar PFD ile beraber görülebilir PFD'li hastaların yaklaşık \%2-3 ünde McCune Albright sendromu (FD, Puberte prekoks ve aynı tarafta cafe au lait lekeleri) nadir olarak Mazabraud Sendromu (FD, renal fosfat kaybı, yumuşak doku miksoması) rastlanır $[3,6,8,9]$. 
Radyolojik bulgular FD de değişkendir. Lezyon iyi sınırlı ve radyolüsent, metafiz veya diafizde yerleşimli litik özellik gösteren buzlu cam dansitesinde lezyonlar olarak görülürler. Kotlarda FD fusiform bir genişleme ve multisptalı görünüme yol açar. Toraks CT, FD'nin özelliklerini göstermesi nedeniyle kullanılan en etkili radyolojik araçtır, lezyonun sklerotik sınırları ve korteks detayları ayrıntılı görüntülenebilir. CT incelemesinde lezyonda amorf veya düzensiz kalsifikasyon sık görülür Lezyonun vaskülaritesine bağlı olarak kontrast madde kullanımı ile lezyonun belirginleşmesi sağlanabilir [1,2]. Üç boyutlu kemik BT lezyonun sınırlarının net olarak belirlenmesinde ve cerrahi rezeksiyon sınırlarını belirlemede yadımcıdır. Fibröz displazinin manyetik rezonans görüntüleme özellikleri değişkendir, fibröz doku miktarı ve derecesi, selülarite, kollajen, trabekülasyon ve kistik veya hemorajik dejenerasyona gibi faktörlere bağlıdır ve FD'yi diğer kemik tümörlerinden ayırıcı tanıda kullanışsızdır ancak FD’nin çevre dokularla ilişkisini ortaya çıkarmada kullanılabilir. Kemik sintigrafisi spesifik değildir ancak lezyonun yaygınlığını ve sınırlarını belirlemede kullanılabilir. PET/CT'nin ayırıcı tanıda yeri yoktur çünkü FD benzeri benign patolojilerdeki hiperfiksasyon yalancı pozitiflik kaynağıdır [3] . Bizim hastamızda radyolojik olarak kesin ayırıcı tanı yapılamamıştır.

Histopatolojik olarak farklı modeller tarif edilmesine rağmen genellikle makroskopik olarak fibröz displazi iyi sınırlı, değişik boyutlarda intramedüller lezyonlardan oluşur. Büyük boyutlardaki lezyonlar kemiği genişleterek şeklini bozabilir. Mikroskopik incelemede selülaritesi değişken fibroblastik stromda çin alfabesindeki harflere benzer kıvrımlanma gösteren kemik trabekülaları izlenir. Kemik trabekulaları çevresinde osteoblastik proliferasyon bulunmaz. Ultrastrüktürel düzeyde dağınık görünümde olan kemik trabekülleri çevresinde fibroblast benzeri özelliklere sahip anormal osteoblastlar görülebilir. Ayırıcı tanıda düşük gradeli osteosarkoma, fibrosarkoma, anevrizmal kemik kisti, Paget hastalığı akla gelmelidir $[1,3,7,8,9]$.

MFD de malign değişim \%0,5 rapor edilmişken Mc Cune sendromunda bu oran \%4'e kadar çıkmaktadır. Radyoterapinin malign dönüşümde faktör olduğu iddia edilmektedir. Özellikle hızlı büyüme ve ağrının gözlenmesi, kanda alkalen fosfatazın yükselmesi malign dönüşüm habercisi olabilir. Malign değişim osteosarkom, fibrosarkom, kondrosarkom ve malign fibröz histiostom olarak rapor edilmiştir $[1,3,6]$.

FD tedavisinde asemptomatik ve stabil hastalarda gözlem bir seçenek olabilir, semptomatik lezyonlarda semptomların kontrolü ve ayırıcının tanının yapılabilmesi için cerrahi endikedir. Patoloji sonucu "polistotic tip" olarak rapor edilen vakalarda ayrıntılı endokrinolojik incelemeye ihtiyaç vardır. Cerrahi "en bloc rezeksiyon" şeklindedir nüks açısından aralıklı takip önerilir [1,3,6,8,9]. Bizim hastamızda olduğu gibi radyolojik olarak ayırıc tanısı yapılamayan ileri yaşlarda görülebilen vakalarda malignite ihtimalini de ekarte etmek amacıyla gözlem olmaksızın cerrahi rezeksiyon doğru bir yaklaşımdır.

Sonuç olarak FD'nin tek kot tutulum yaptığı vakalarda ayırıcı tanı, malign dönüşüm ihtimali, kotta destrüksiyona ve patolojik kırıklara yol açabilme potansiyeli nedeniyle radyolojik olarak ayırıcı tanısı yapılamayanlarda, biyopsi sonrası, ayırıcı tanısı yapılabilenlerde ise biyopsi doğrulaması olmaksızın yapılan en bloc rezeksiyonun etkili bir tedavi yöntemi olduğunu düşünüyoruz.

\section{Maddi Destek ve Çıkar İlişkisi}

Çalışmayı maddi olarak destekleyen kişi/kuruluş yoktur ve yazarların çıkara dayalı bir ilişkisi yoktur.

\section{Kaynaklar}

1. Mahadevappa A, Patel S, Ravishankar S, Manjunath GV. Monostotic Fibrous Dysplasia of the Rib: A Case Report. Case Reports in Orthopedics 2012; Article ID 690914: 5.

2. Altuntaş $B, A y d ı n ~ Y$, Eroğlu A. Bening chest wall tumors and their surgical treatment. Anatol J Med Sci 2016; 2: 1-4.

3. Traibi A, El Oueriachi F, El Hammoumi M, Al Bouzidi A, El Hassane K. Monostotic fibrous dysplasia of the ribs. Interactive CardioVascular and Thoracic Surgery. 2012; 14: 41-43.

4. Aydoğdu K, Fındık G, Ağaçkıran Y ve ark. Kaburgaların Fibröz Displazisi ve Cerrahi Tedavisi: 14 olgunun değerlendirilmesi. Solunum Hastalıkları 2012; 23: 1-4.

5. Aydoğdu Kıreşi D, Emlik D, Vural A, Ödev K. Toraks duvarı tümörlerinde radyolojik bulgular. Tanısal ve Girişimsel Radyoloji 2002; 8: 216-21.

6. Byrns K, Zhou D, Freedman L, Rubin AN. Fibrous Dysplasia of the Rib. RadioGraphics 2015; 35: 2049-52.

7. Tateishi U, Gladish GW, Kusumoto M. Chest wall tumors: radiologic findings and pathologic correlation: part 1. Benign tumors. Radiographics 2003; 23: 1477-90.

8. Hosalkar RM, Pathak J, Swain N, Mohanty N. Pagetoid polyostotic fibrous dysplasia. BMJ Case Rep 2015; doi:10.1136/bcr-2014-209149.

9. Ahmad Z, Zubair I. Fibrous dysplasia of rib presenting as a cystic mass in the lung. Oxford Medical Case Reports 2015; 2: 196-99. 